\title{
Gambaran Cairan Serebrospinal pada Pasien Anak dengan Infeksi Susunan Saraf Pusat di Rumah Sakit Rujukan Jawa Barat
}

\author{
Ariel Bagoes Prakoso, Mia Milanti Dewi, Adhi Kristianto Sugianli \\ Departemen Ilmu Kesehatan Anak Fakultas KedokteranUniversitas Padjadjaran/Rumah Sakit Dr. Hasan Sadikin, \\ Bandung
}

Latar belakang. Infeksi pada susunan saraf pusat (SSP) dapat memberikan dampak permanen, seperti ganguan fungsi kognitif dan fisik apabila terlambat mendapatkan penanganan. Perubahan komposisi cairan serebrospinalis (LCS) dapat digunakan sebagai indikator pada infeksi SSP. Studi kepustakaan pada karakteristik perubahan komposisi LCS masih sulit ditemukan sehingga diperlukan studi lebih lanjut mengenai hal ini.

Tujuan. Mengetahui gambaran LCS pada pasien anak dengan infeksi susunan saraf pusat.

Metode. Deskriptif potong lintang terhadap rekam medis pasien anak dengan infeksi susunan saraf pusat rawat inap di RSUP Dokter Hasan Sadikin Bandung periode Januari 2015-Agustus 2019.

Hasil. Dari 211 subjek penelitian dengan rentang usia 1 bulan hingga 18 tahun diperoleh rerata usia 7,18, median usia 5, dan standar deviasi usia 6,53. Diperoleh pada kelompok usia 1 bulan-2 tahun 39,8\%, 3-6 tahun 14,7\%;, 7-12 tahun 12,8\%; dan 13-18 tahun $32,7 \%$. Diperoleh 45,5\% sampel merupakan infeksi tuberkulosis (TB), 21,3\% sampel infeksi virus, 9,5\% sampel infeksi bakteri, dan $23,7 \%$ sampel infeksi tidak spesifik.

Kesimpulan. Pemeriksaan LCS sangat penting dilakukan untuk menunjang diagnosis infeksi SSP. Sebagian besar LCS menunjukkan gambaran infeksi yang disebabkan oleh TB. Sari Pediatri 2020;21(6):339-45

Kata kunci: cairan serebrospinalis, infeksi, meningitis, ensefalitis

\section{Cerebrospinal Fluid Analysis in Pediatric Patient with Central Nervous System Infection at West Java's Referral Hospital}

Ariel Bagoes Prakoso, Mia Milanti Dewi, Adhi Kristianto Sugianli

Background. Infection on central nervous system (CNS) may cause permanent damage such as impaired cognitive and physical function especially on a pediatric patients if not treated promptly. Changes in cerebrospinal fluid (CSF) composition can be used as an indicator on CNS infection. Even so, literature studies on the characteristics of changes in the composition of CSF are still difficult to find, so further studies are needed on this matter.

Objective. Knowing the characteristic of CSF changes in a pediatric patients with CNS infection.

Methods. A descriptive cross-sectional study of the medical record of pediatric in patients with CNS infection at RSUP Dokter Hasan Sadikin Bandung in January 2015-August 2019 period.

Result. From 211 research subject with age range of 1 month-18 years old, the mean age was obtained: 7,18; median age: 5; age standard deviation: 6,53. Consists of 1 month-2 years old age group (39.,8\%); 3-6 years old (14,7\%); 7-12 years old (12,8\%); $13-18$ years old (32,7\%). 45,5\% of the sample were tuberculosis infections; $21,3 \%$ were viral infections; $9,5 \%$ were bacterial infections; $23,7 \%$ were unspecified infections.

Conclusion. CSF analysis is very important to support the diagnosis of CNS infection. Most of the analyzed CSF in this research shows characteristic caused by tuberculosis infections. Sari Pediatri 2020;21(6):339-45

Keywords: cerebrospinal fluid, infection, meningitis, encephalitis

Alamat korespondensi: Mia Milanti Dewi. Departemen Ilmu Kesehatan Anak Fakultas Kedokteran Universitas Padjadjaran, Jalan Pasteur No. 38 Bandung 40161. Email: miamilanti@gmail.com 
Ariel Bagoes Prakoso dkk: Gambaran cairan serebrospinal pada pasien anak dengan infeksi susunan saraf pusat

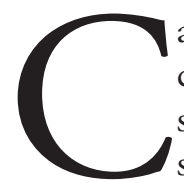

airan serebrospinal (LCS) merupakan cairan bening yang bersirkulasi di sekitar susunan saraf pusat (SSP). Peran LCS sebagai substansi aktif dan dinamis yang berfungsi untuk menjaga keseimbangan kimia pada SSP dan juga sebagai bantalan untuk menjaga SSP dari trauma mekanis. Asal LCS adalah dari plasma yang mengalami ultra-filtrasi. ${ }^{1}$ Perubahan komposisi LCS merupakan indikator yang berguna sebagai alat diagnosis serta evaluasi pada penyakit yang melibatkan SSP. Salah satu penyebab perubahan pada komposisi LCS adalah pada kasus infeksi SSP. ${ }^{2}$

Infeksi pada SSP dapat disebabkan oleh berbagai jenis mikroorganisme, di antaranya adalah virus, bakteri, fungi, maupun parasit. Bentuk infeksinya dapat terjadi secara sistemik melibatkan daerah meningen (meningitis) atau memengaruhi jaringan parenkim otak di bawahnya (ensefalitis). Infeksi juga dapat membentuk lesi lokal yang menyerupai tumor. Tiap jenis infeksi memiliki karakteristik khusus dalam pengaruhnya terhadap perubahan komposisi LCS. ${ }^{3}$

Meningitis merupakan salah satu penyebab kematian terbesar pada anak dengan usia di bawah lima tahun. ${ }^{4}$ Pada tahun 2015, meningitis mengakibatkan sekitar 300.000 kematian di seluruh dunia. Angka kematian pada kasus meningitis akibat infeksi bakteri masih tergolong tinggi (16\%-32\%), terutama pada negara berkembang. ${ }^{5}$ Selain itu, meningitis juga dapat mengakibatkan gangguan jangka panjang atau sequelae berupa penurunan fungsi kognitif, gangguan pendengaran, epilepsi, dan kelumpuhan. Kemungkinan terjadinya efek sequelae semakin tinggi seiring dengan lambatnya diagnosis dan terapi. Akibatnya, dibutuhkan penanganan yang cepat dan tepat untuk menyelamatkan nyawa pasien dan meminimalisir efek sequelae. ${ }^{4}$

Analisis LCS dapat membantu untuk menetapkan diagnosis. Perubahan karakteristik pada LCS, seperti kadar leukosit, protein, glukosa, serta penampakan makroskopisnya dapat memberikan gambaran mengenai penyakit yang diderita pasien. Kultur dan pemeriksaan polymerase chain reaction (PCR) juga dapat dilakukan pada LCS untuk mengidentifikasi patogen penyebab penyakit. Diagnosis yang pasti sebelum memulai terapi mengakibatkan pemberian obat dapat dilakukan dengan tepat untuk mencegah adanya efek samping obat yang tidak perlu. ${ }^{6}$ Pada saat ini, penelitian dan studi kepustakaan yang terbaru mengenai, gambaran LCS pada pasien anak dengan infeksi susunan saraf pusat di RSUP Dr. Hasan Sadikin Bandung masih cukup sulit ditemukan. Di samping itu, angka kematian yang masih cukup tinggi di dunia menuntut para klinisi untuk mendeteksi dini penyakit ini guna memberikan penanganan yang cepat dan tepat. Kondisi-kondisi tersebut mendorong penulis untuk melakukan penelitian mengenai gambaran LCS pada pasien anak dengan infeksi susunan saraf pusat di RSUP Dr. Hasan Sadikin Bandung.

\section{Metode}

Penelitian dilakukan dengan metode deskriptif potong lintang terhadap rekam medis pasien dengan infeksi saraf pusat yang menjalani rawat inap di poli anak Rumah Sakit Dokter Hasan Sadikin Bandung periode Januari 2015 hingga Agustus 2019. Sampel ditentukan dengan teknik total sampling. Data yang digunakan adalah data sekunder yang diperoleh melalui rekam medis di RSUP Dokter Hasan Sadikin Bandung. Kriteria inklusi, yaitu anak dengan usia satu bulan hingga 18 tahun, tersedia hasil pemeriksaan LCS, dan memiliki kode ICD berupa A17.0, A86, A87, G00.9, G03.0, G04.8, G04.9. Kriteria eksklusi yaitu data tidak dapat ditemukan dan data tidak dapat diinterpretasi. Penelitian ini telah mendapatkan persetujuan dari Komite Etik Penelitian Universitas Padjadjaran dengan nomer lisensi 993/UN6.KEP/EC/2019.

\section{Hasil}

Melalui kriteria penelitian, diperoleh jumlah sampel sebanyak 410 data. Dari jumlah tersebut sampel yang berhasil diperoleh adalah sejumlah 243 data (59,3\%). Selama proses pengambilan sampel, ditemukan 32 data yang tidak terdapat hasil pemeriksaan LCS. Dengan demikian, total sampel yang dianalisis dalam penelitian ini adalah 211 data $(86,8 \%)$.

Berdasarkan tabel satu, diperoleh data bahwa kasus infeksi pada SSP paling banyak terjadi pada anak dengan kelompok usia 1 bulan-2 tahun (39,8\%). Infeksi paling banyak disebabkan oleh infeksi TB $(45,5 \%)$ yang utamanya terjadi pada kelompok usia remaja (47,9\%). Kasus infeksi SSP pada anak juga lebih sering menyerang laki-laki $(54,5 \%)$ dibanding perempuan $(45,5 \%)$, tetapi perbedaannya tidak signifikan. 
Tabel 1. Karakteristik pasien anak dengan infeksi SSP

\begin{tabular}{|c|c|c|c|c|}
\hline \multirow{3}{*}{ Karakteristik } & Infeksi TB & Infeksi virus & Infeksi bakteri & Infeksi tidak spesifik \\
\hline & $(n=96)$ & $(\mathrm{n}=45)$ & $(\mathrm{n}=20)$ & $(\mathrm{n}=50)$ \\
\hline & $\%$ & $\%$ & $\mathrm{n} \quad \%$ & $\%$ \\
\hline \multicolumn{5}{|l|}{ Usia } \\
\hline 1 bulan- 2 tahun & $26(27)$ & $23(51,1)$ & $12(60)$ & $23(46)$ \\
\hline 3-6 tahun & $12(12,5)$ & $6(13,3)$ & $2(10)$ & $11(22)$ \\
\hline 7-12 tahun & $12(12,5)$ & $6(13,3)$ & $4(20)$ & $5(10)$ \\
\hline 13-18 tahun & $46(48)$ & $10(22,2)$ & $2(10)$ & $11(22)$ \\
\hline \multicolumn{5}{|l|}{ Jenis kelamin } \\
\hline Laki-laki & $48(50)$ & $19(42,2)$ & $16(80)$ & $32(64)$ \\
\hline Perempuan & $48(50)$ & $26(57,8)$ & $4(20)$ & $18(36)$ \\
\hline
\end{tabular}

Tabel 2. Hasil pemeriksaan LCS

\begin{tabular}{|c|c|c|c|c|}
\hline \multirow{3}{*}{ Karakteristik } & \multirow{2}{*}{$\begin{array}{c}\text { Infeksi TB } \\
(\mathrm{n}=96)\end{array}$} & Infeksi virus & Infeksi bakteri & Infeksi tidak spesifik \\
\hline & & $(\mathrm{n}=45)$ & $(\mathrm{n}=20)$ & $(\mathrm{n}=50)$ \\
\hline & $\mathrm{n} \quad \%$ & $\mathrm{n} \quad \%$ & $\mathrm{n} \quad \%$ & $\%$ \\
\hline \multicolumn{5}{|l|}{ Warna } \\
\hline Tidak berwarna & $72(7)$ & $41(91,1)$ & $11(55)$ & $40(80)$ \\
\hline Merah & $9(9,4)$ & $2(4,4)$ & $1(5)$ & $1(2)$ \\
\hline Xantochrome & $15(15,6)$ & $2(4,4)$ & $8(40)$ & $6(12)$ \\
\hline \multicolumn{5}{|l|}{ Jumlah sel } \\
\hline Normal & $14(14,6)$ & $30(66,7)$ & $3(15)$ & $18(36)$ \\
\hline Meningkat & $69(71,9)$ & $15(33,3)$ & $7(35)$ & $29(58)$ \\
\hline Sangat meningkat & $13(13,5)$ & $0(0)$ & $10(50)$ & $3(6)$ \\
\hline \multicolumn{5}{|l|}{ Persen neutrofil } \\
\hline $0-25 \%$ & $52(54,2)$ & $31(68,9)$ & $7(35)$ & $37(74)$ \\
\hline $26-50 \%$ & $24(25)$ & $8(17,8)$ & $5(25)$ & $5(10)$ \\
\hline $51-75 \%$ & $13(13,5)$ & $1(2,2)$ & $5(25)$ & $3(6)$ \\
\hline $76-100 \%$ & $7(7,3)$ & $5(11,1)$ & $3(15)$ & $5(10)$ \\
\hline \multicolumn{5}{|l|}{ Persen limfosit } \\
\hline $0-25 \%$ & $10(10,4)$ & $6(13,3)$ & $4(20)$ & $5(10)$ \\
\hline $26-50 \%$ & $12(12,5)$ & $6(13,3)$ & $8(40)$ & $4(8)$ \\
\hline $51-75 \%$ & $24(25)$ & $5(11,1)$ & $2(10)$ & $6(12)$ \\
\hline $76-100 \%$ & $50(52,1)$ & $28(62,2)$ & $6(30)$ & $35(70)$ \\
\hline \multicolumn{5}{|l|}{ Kadar protein } \\
\hline Menurun & $1(1)$ & $3(6,7)$ & $0(0)$ & $1(2)$ \\
\hline Normal & $19(19,8)$ & $31(68,9)$ & $3(15)$ & $23(46)$ \\
\hline Meningkat & $50(52,1)$ & $11(24,4)$ & $8(40)$ & $12(24)$ \\
\hline Sangat meningkat & $26(27,1)$ & $0(0)$ & $9(45)$ & $14(28)$ \\
\hline \multicolumn{5}{|l|}{ Kadar glukosa } \\
\hline Menurun & $51(53,1)$ & $1(2,2)$ & $10(50)$ & $17(34)$ \\
\hline Normal & $37(38,5)$ & $36(80)$ & $9(45)$ & $27(54)$ \\
\hline Meningkat & $8(8,3)$ & $8(17,8)$ & $1(5)$ & $6(12)$ \\
\hline
\end{tabular}

Jumlah Leukosit: Normal: <5 sel/ $\mathrm{mm}^{3}$; Meningkat: 5-300 sel $/ \mathrm{mm}^{3}$; Sangat Meningkat: $>301 \mathrm{sel} / \mathrm{mm}^{3}$; Kadar Protein: Menurun: 0-14 mg/ dL; Normal: 15-45 mg/dL; Meningkat: 46-200 mg/dL; Sangat Meningkat: > 200 mg/dL; Kadar Glukosa: Menurun: <45 mg/dL; Normal: 45-80 mg/dL; Meningkat: $>80 \mathrm{mg} / \mathrm{dL}$. 
Ariel Bagoes Prakoso dkk: Gambaran cairan serebrospinal pada pasien anak dengan infeksi susunan saraf pusat

Tabel 3. Manifestasi klinis dan hasil pemeriksaan neurologis dengan infeksi SSP

\begin{tabular}{|c|c|c|c|c|}
\hline \multirow{2}{*}{ Tanda dan gejala } & $(\mathrm{n}=96)$ & $\begin{array}{l}\text { Infeksi virus } \\
(\mathrm{n}=45)\end{array}$ & $\frac{\text { Infeksi bakteri }}{(\mathrm{n}=20)}$ & $\frac{\text { Infeksi tidak spesifik }}{(\mathrm{n}=50)}$ \\
\hline & n $\quad \%$ & $\mathrm{n} \quad \%$ & $\mathrm{n} \quad \%$ & $\%$ \\
\hline \multicolumn{5}{|l|}{ Manifestasi klinis } \\
\hline Panas badan & $86(89)$ & $43(95,5)$ & $20(100)$ & $44(88)$ \\
\hline Diare & $8(8,3)$ & $18(40)$ & $4(20)$ & $13(26)$ \\
\hline Batuk & $37(38,5)$ & $20(44,4)$ & $9(45)$ & $18(36)$ \\
\hline Nyeri kepala & $37(38,5)$ & $3(6,7)$ & $3(15)$ & $10(20)$ \\
\hline Mual & $19(19,8)$ & $12(26,7)$ & $3(15)$ & $11(22)$ \\
\hline Muntah & $40(41,7)$ & $13(28,9)$ & $4(20)$ & $17(34)$ \\
\hline Penurunan kesadaran & $77(80,2)$ & $28(62,2)$ & $15(75)$ & $29(58)$ \\
\hline Kejang & $47(49)$ & $35(77,8)$ & $10(50)$ & $42(84)$ \\
\hline \multicolumn{5}{|l|}{ Pemeriksaan neurologis } \\
\hline Kaku kuduk & $60(62,5)$ & $15(33,3)$ & $14(70)$ & $28(56)$ \\
\hline Brudzinsky's sign & $28(46,7)$ & $6(13,3)$ & $5(25)$ & $10(20)$ \\
\hline Chaddock's sign & $35(36,4)$ & $9(20)$ & $11(55)$ & $20(40)$ \\
\hline Babinsky’s sign & $55(57,2)$ & $17(37,8)$ & $13(65)$ & $30(60)$ \\
\hline
\end{tabular}

Nilai acuan dalam menentukan peningkatan tiap komponen pada LCS. Berdasarkan hasil pemeriksaan LCS, hampir semua agen penyebab infeksi SSP dapat merubah komposisi LCS menjadi tidak normal. 75\% kasus dengan peningkatan jumlah leukosit melebihi 1000 sel diakibatkan oleh infeksi bakteri. Infeksi yang disebabkan oleh virus memiliki efek terkecil terhadap perubahan komposisi LCS. Contohnya pada jumlah sel leukosit, 66,7\% kasus masih dalam kategori normal, sisa 33,3\% kasus yang abnormal juga hanya mengalami sedikit peningkatan (6-300 sel).

Hasil kultur organisme dari beberapa kasus meningitis bakterialis adalah Staphylococcus hominis, Staphylococcus aureus, Streptococcus agalactiae, Streptococcus pneumoniae, dan Klebsiella pneumoniae. Jumlah sel sangat meningkat pada infeksi $K$. pneumoniae dan $S$. aureus $\left(>1000 \mathrm{sel} / \mathrm{mm}^{3}\right)$. Kemudian kadar protein sangat meningkat pada infesksi $S$. hominis (>3000 mg/dL).

Tabel tiga menggambarkan gejala klinis yang ditemukan pada pasien. Diketahui pada kasus infeksi SSP hampir selalu menimbulkan gejala panas badan (TB: $89 \%$; virus: 95,5\%; bakteri: 100\%; lainnya: $88 \%)$. Diare paling sering ditemukan pada kasus infeksi virus $(41,9 \%)$. Penurunan kesadaran lebih sering terjadi pada kasus infeksi oleh TB $(80,2 \%)$ dan bakteri lainnya (75\%).

Pada hasil pemeriksaan neurologis, 70\% kasus infeksi oleh bakteri menyebabkan kaku kuduk. Brudzinsky sign paling banyak ditemukan pada kasus infeksi oleh TB (46,7\%). Secara keseluruhan, kasus infeksi oleh virus memiliki signifikansi terkecil terhadap keadaan neurologis pasien dibanding dengan penyebab lainnya.

\section{Pembahasan}

Berdasarkan hasil penelitian ditemukan bahwa kasus infeksi SSP pada anak di RSUP Dokter Hasan Sadikin Bandung paling banyak disebabkan oleh infeksi TB $(45,5 \%)$. Hal ini sesuai dengan keadaan di Indonesia yang masih memiliki prevalensi kasus infeksi TB yang tinggi. ${ }^{7}$ Kasus infeksi juga paling banyak terjadi pada anak dengan kelompok usia satu bulan-2 tahun (39,8\%). Sesuai dengan yang dilaporkan Nguyen ${ }^{8}$ pada penelitiannya di Vietnam. Nguyen melaporkan bahwa anak dengan usia di bawah dua tahun berisiko lebih tinggi untuk mengalami infeksi SSP akibat imaturitas dari sistem imun.

Hasil pemeriksaan LCS pada infeksi SSP pada dasarnya memiliki karakteristik yang serupa. Infeksi akan mengakibatkan peningkatan kadar protein akibat fungsi ultra-filtrasi pleksus koroidal terganggu sehingga molekul protein dapat memasuki LCS. ${ }^{9}$ Penurunan kadar glukosa pada LCS akibat efek 
katabolisme glukosa oleh patogen. ${ }^{10}$ Patogen juga akan memicu reaksi inflamasi sehingga terjadi kenaikan jumlah leukosit pada LCS. Perubahan komposisi ini memberikan efek perubahan warna dan mengeruhnya LCS sehingga analisis yang dapat dilakukan adalah tingkat perubahan dari tiap parameter tersebut.'

Pada infeksi TB dan bakteri yang ditemukan, kadar protein sebagian besar sangat meningkat, kadar glukosa turun, jumlah sel leukosit sangat meningkat, dapat mencapai $>1000$ sel. Temuan ini sesuai dengan hasil penelitian sebelumnya yang dilakukan oleh Shenoy ${ }^{11}$ di India. Namun, terdapat kasus infeksi TB yang jumlah selnya mengalami kenaikan $>1000$ sel. Hal ini mungkin dapat terjadi akibat adanya infeksi oleh bakteri lain bersamaan dengan TB. Selain itu, Shenoy juga melaporkan bahwa pada infeksi bakteri sel yang mendominasi adalah sel neutrofil, sedangkan TB didominasi sel monosit. Pada hasil penelitian, pernyataan tersebut sesuai untuk infeksi TB, tetapi pada infeksi bakteri justru kadar neutrofil mengalami penurunan. Kemudian hasil temuan warna dan kejernihan LCS pada penelitian kami ditemukan perubahan warna menjadi kuning dan merah. Perubahan warna ini diakibatkan oleh masuknya komponen darah ke dalam LCS sebagai efek dari peradangan SSP. ${ }^{12}$

Pada infeksi virus, masih ditemukan banyak parameter LCS yang normal. Virus tidak termasuk patogen yang memecah glukosa, seperti bakteri dan fungi. Karenanya, meskipun terjadi infeksi yang berat dan ekstensif kadar glukosa tidak menurun sebanyak patogen lain. ${ }^{10}$ Hingga saat ini, masih belum ditemukan patofisiologi yang jelas mengenai perubahan spesifik dari tiap parameter LCS, seperti yang dilaporkan oleh Thuong. ${ }^{13}$ Pemeriksaan LCS juga dipengaruhi oleh prosedur pengambilan sampel yang kurang tepat, kadar patogen itu sendiri, dan penggunaan antibiotik yang dapat mengakibatkan hasil pemeriksaan LCS mengalami perubahan atau tampak normal. ${ }^{11}$

Berbagai jenis infeksi yang terjadi pada tubuh manusia dapat memicu timbulnya demam atau panas badan. ${ }^{14}$ Pada sampel yang diteliti, hampir seluruhnya ditemukan gejala panas badan $(91,5 \%)$, terutama infeksi bakteri yang selalu menimbulkan gejala demam pada setiap kasusnya (100\%). Hanya terdapat 8,5\% sampel yang tidak ditemukan gejala demam. Hal ini biasanya ditemukan pada pasien yang telah terdiagnosis infeksi TB paru, tetapi tidak menjalani pengobatan secara lengkap. Dengan demikian, penyakit akan berkembang menjadi TB ekstra-paru dan menyerang SSP tanpa disertai dengan demam karena bakteri sudah menginfeksi sejak lama. Seperti laporan penelitian oleh Marx ${ }^{15}$ di Amerika Serikat. Marx melaporkan bahwa meningitis TB biasanya menimbulkan gejala subakut sehingga pasien kadang tidak mengeluhkan gejala tersebut.

Selain itu, pada penelitian kami ditemukan bahwa kasus infeksi SSP akibat TB juga menimbulkan gejala masalah pencernaan berupa muntah $(41,7 \%)$ yang jarang disertai dengan diare $(8,3 \%)$. Sesuai dengan laporan penelitian Butler ${ }^{16}$ di Amerika Serikat. Butler melaporkan bahwa salah satu gejala klinis infeksi SSP oleh TB adalah adanya muntah tanpa disertai dengan diare. Kasus infeksi ini tidak selalu disertai dengan keluhan batuk (keluhan batuk $(38,5 \%)$ yang menandakan bahwa infeksi SSP dapat terjadi tanpa disertai dengan adanya infeksi paru. ${ }^{17}$ Chin ${ }^{17}$ melaporkan bahwa gejala penurunan kesadaran yang banyak terjadi pada infeksi TB $(80,2 \%)$ disertai dengan gejala neurologis, seperti kaku kuduk, brudzinsky sign, dan lainnya. Hal tersebut menandakan tingkat keparahan penyakit yang lebih lanjut. Sebagai rumah sakit rujukan utama Jawa Barat, pasien rujukan RSUP Dokter Hasan Sadikin merupakan pasien yang sudah mengalami komplikasi berat.

Gejala gangguan pencernaan berupa diare paling banyak terjadi pada kasus infeksi oleh virus $(41,9 \%)$. $\mathrm{Hal}$ ini terjadi kemungkinan diakibatkan enterovirus, yang dapat menginfeksi pasien melalui saluran cerna. Pernyataan tersebut didukung oleh penelitan yang dilakukan oleh $\mathrm{Ai}^{18}$ di Tiongkok. Kasus infeksi akibat virus juga menimbulkan gejala awal, seperti batuk pilek sehingga pada penelitian ini banyak pasien yang mengeluhkan batuk-pilek. ${ }^{18}$ Infeksi SSP akibat virus juga dikatakan sebagai self-limiting disease, terlihat dari luaran manifestasi klinis dan hasil pemeriksaan LCS yang hanya mengalami sedikit perubahan. Gejala neurologis, seperti kaku kuduk dan refleks meningen lainnya juga tidak se-signifikan patogen lainnya. Namun, infeksi virus biasanya menyerang bagian parenkim otak sehingga menimbulkan insiden kejang yang tinggi. ${ }^{18}$ Storz ${ }^{19}$ melaporkan bahwa pada infeksi bakteri organisme yang paling sering ditemukan adalah Haemophilus influenzae, dilanjutkan dengan Streptococcus pneumoniae, dan Neisseria meningitidis. Gejala umum berupa demam, batuk, penurunan kesadaran, gejala neurologis, seperti kaku kuduk 
dan kejang. ${ }^{1}$ Temuan tersebut selaras dengan hasil penelitian kami, 100\% pasien dengan infeksi bakteri mengeluhkan demam, 45\% mengeluhkan batuk, dan 75\% disertai penurunan kesadaran. Pemeriksaan neurologis juga menunjukkan $70 \%$ pasien mengalami kaku kuduk dan 50\% pasien kejang.

Gangguan neurologis pada infeksi SSP oleh bakteri diakibatkan oleh keadaan pro-inflammatory pada SSP. Bakteri akan menginisiasi respon peradangan dan aktivasi dari mikroglial. Aktivasi dari mikroglial memicu terjadinya immunological pathway sehingga memunculkan cytokines, chemokines, reactive oxygen, dan nitrogen species. Keadaan ini akan membantu tubuh untuk menyingkirkan patogen invasif, tetapi keadaan tersebut apabila berkepanjangan justru akan memicu terjadinya kerusakan sel saraf sehingga gejala gangguan neurologis dapat muncul. ${ }^{20}$

Temuan lain dari penelitian kami adalah jarang ditemukannya kasus pasien infeksi bakteri yang mengeluhkan nyeri kepala, mual, maupun muntah. Van de Beek ${ }^{21}$ melaporkan bahwa keluhan nyeri kepala hanya muncul pada $2 \%-9 \%$ kasus dengan anak umur 0-1 tahun dan muncul 75\% pada anak dengan umur di atas 5 tahun. Pada penelitian kami, 60\% sampel infeksi bakteri merupakan anak dengan usia 0-2 tahun sehingga keluhan nyeri kepala dan keluhan lain sulit dikonfirmasi, terbanyak adalah tanda-tanda nonspesifik yang dapat diperiksa oleh klinisi. ${ }^{19}$

Mengenai penurunan kesadaran, pada beberapa pasien yang sudah cukup dewasa terdapat perubahan perilaku menjadi agresif. Untuk itu, pasien biasanya dirujuk dari bangsal kejiwaan sebelum akhirnya ditegakkan bahwa pasien mengalami penurunan kesadaran akibat infeksi pada SSP. Keadaan ini berhubungan dengan kenaikan kadar protein pada LCS pasien. Sesuai dengan penelitian Khanna di India. ${ }^{22}$

Pada infeksi tidak spesifik, diagnosis yang tertera dalam rekam medis di antaranya adalah meningitis aseptik, meningitis serosa, dan meningitis anti-Nmethyl-D-aspartate receptor (NMDAR). Pada kasus tersebut, ditemukan berbagai macam gejala yang menunjukkan bahwa ada gangguan pada SSP pasien sehingga memicu klinisi untuk menetapkan diagnosis tersebut. Namun, gejala tersebut tidak dikelompokkan secara spesifik. Manifestasi klinis yang muncul dari tiap kasus sangat beragam. Oleh sebab itu, penentuan karakteristik yang dapat digunakan untuk kemudian hari sulit dilakukan.

Kekurangan penelitian ini, antara lain, akibat data diperoleh melalui data sekunder, banyak data rekam medis yang tidak dapat diakses hingga akhir masa penelitian. Kemudian ada kemungkinan data yang terlewat akibat diagnosis infeksi SSP tidak ditulis sebagai diagnosis utama. Penelitian ini merupakan penelitian awal mengenai gambaran perubahan LCS pada kasus anak infeksi SSP sehingga pada penelitian selanjutnya dapat dilaksanakan studi prospektif untuk menggambarkan hubungan perubahan LCS dengan progresivitas penyakit pada pasien. Kemudian, parameter dapat lebih diperjelas, apakah pasien yang sudah menerima pemberian antibiotik, dan dicantumkan kapan dilakukan prosedur pungsi lumbal dibanding onset penyakitnya.

\section{Kesimpulan}

Kasus infeksi SSP pada anak di RSUP Dokter Hasan Sadikin Bandung paling sering terjadi pada kelompok usia 1 bulan-2 tahun (39,8\%), banyak menyerang lakilaki $(54,5 \%)$, dan penyebab utamanya adalah akibat infeksi TB (45,5\%). Pada penelitian ini, manifestasi klinis dan perubahan komposisi LCS terlihat jelas pada infeksi TB dan bakteri. Sementara pada infeksi virus, manifestasi klinis dan perubahan LCS tidak terlalu bermakna.

\section{Daftar pustaka}

1. Khasawneh AH, Garling RJ, Harris CA. Cerebrospinal fluid circulation: What do we know and how do we know it? Brain Circ 2018;4:14-8.

2. Spector R, Robert Snodgrass S, Johanson CE. A balanced view of the cerebrospinal fluid composition and functions: Focus on adult humans. Exp Neurol 2015;273:57-68.

3. Brown BL, Fidell A, Ingolia G, Murad E, Beckham JD. Infectious causes and outcomes in patients presenting with cerebral spinal fluid pleocytosis. J Neurovirol 2019:25:448-56.

4. Roca A, Bassat Q, Morais L, Machevo S, Sigaúque B, O'Callaghan C, dkk. Surveillance of Acute Bacterial Meningitis among Children Admitted to a District Hospital in Rural Mozambique. Clin Infect Dis 2009;48:S172-80.

5. Kim KS. Acute bacterial meningitis in infants and children. Lancet Infect Dis 2010;10:32-42.

6. Amini M, Bahador M, Bahador M. Common cause and cerebrospinal fluid changes of acute bacterial meningitis. Iran J Pathol 2009;4:75-9. 
7. Collins D, Hafidz F, Mustikawati D. The economic burden of tuberculosis in Indonesia. Int J Tuberc Lung Dis 2017;21:1041-8.

8. Bang ND, Caws M, Truc TT, Duong TN, Dung NH, Ha DTM, dkk. Clinical presentations, diagnosis, mortality and prognostic markers of tuberculous meningitis in Vietnamese children: A prospective descriptive study. BMC Infect Dis 2016;16:1-10.

9. Regeniter A, Kuhle J, Mehling M, Möller H, Wurster U, Freidank H, dkk. A modern approach to CSF analysis: Pathophysiology, clinical application, proof of concept and laboratory reporting. Clin Neurol Neurosurg. 2009;111:313-8.

10. Baud MO, Vitt JR, Robbins NM, Wabl R, Wilson MR, Chow FC, dkk. Pleocytosis is not fully responsible for low CSF glucose in meningitis. Neurol Neuroimmunol NeuroInflamm 2017;5:e425.

11. Shenoy A, Desai H, Mandvekar A. Cerebrospinal fluid - A clinicopathologic analysis. J Assoc Physicians India 2017;65:40-3.

12. Chu KH, Bishop RO, Brown AF. Spectrophotometry, not visual inspection for the detection of xanthochromia in suspected subarachnoid haemorrhage: A debate. EMA - Emerg Med Australas 2015;27:267-72.

13. Thuong NTT, Vinh DN, Hai HT, Thu DDA, Nhat LTH, Heemskerk D, dkk. Pre-treatment cerebrospinal fluid bacterial load correlates with inflammatory response and predicts neurological events during tuberculous meningitis treatment. J Infect Dis 2019;219:986-95.

14. Young P, Saxena M, Bellomo R, Freebairn R, Hammond
N, Van Haren F, dkk. Acetaminophen for fever in critically III patients with suspected infection. N Engl J Med 2015;373:2215-24.

15. Marx GE, Chan ED. Tuberculous Meningitis: Diagnosis and Treatment Overview. Tuberc Res Treat 2011;2011:1-9.

16. Butler P, Shah R, Kas-Osoka O, Galvis AE. Tuberculosis Meningitis in a Immunocompetent Host. Am J Case Rep 2016;17:977-81.

17. Chin JH. Tuberculous meningitis: Diagnostic and therapeutic challenges. Neurol Clin Pract 2014;4:199-205.

18. Ai J, Xie Z, Liu G, Chen Z, Yang Y, Li Y, dkk. Etiology and prognosis of acute viral encephalitis and meningitis in Chinese children: A multicentre prospective study. BMC Infect Dis 2017;17:1-7.

19. Storz C, Schutz C, Tluway A, Matuja W, Schmutzhard E, Winkler AS. Clinical findings and management of patients with meningitis with an emphasis on Haemophilus influenzae meningitis in rural Tanzania. J Neurol Sci 2016;366:52-8.

20. Barichello T, Generoso JS, Simóes LR, Goularte JA, Petronilho F, Saigal P, dkk. Role of Microglial Activation in the Pathophysiology of Bacterial Meningitis. Mol Neurobiol 2016;53:1770-81.

21. Van de Beek D, Cabellos C, Dzupova O, Esposito S, Klein M, Kloek AT, dkk. ESCMID guideline: Diagnosis and treatment of acute bacterial meningitis. Clin Microbiol Infect 2016;22:S37-62.

22. Khanna A, Sinha A, Periwal P, Talwar D. Hyper somnolence in Kleine-Levin syndrome secondary to tuberculous meningitis. Astrocyte 2015;2:52. 